\title{
Isozyme variation in four populations of Penaeus chinensis shrimp
}

WANG Wei-Ji ${ }^{1}$, KONG Jie ${ }^{1}$, BAO Zhen-Min² , DENG Jing-Yao ${ }^{1}$, ZHUANG Zhi-Meng ${ }^{1}$

1 Yellow Sea Fisheries Research Institute , Qingdao 266071

2 Marine Life College, Ocean University of Qingdao, Qingdao 266003

\begin{abstract}
Horizontal starch gel electrophoresis was used to investigate the isozyme genetic variation in Penaeus chinensis shrimp. Each 50 individuals from two wild geographic populations distributed in the China Coast of the Yellow Sea ( YP) and the western coast of Korean Peninsula (KP) , and from two cultivated populations $\left(\mathrm{CP}_{1}\right.$ and $\left.\mathrm{CP}_{2}\right)$ were surveyed. Of 20 loci encoding 12 enzymes, four are polymorphic. The mean proportions of polymorphic loci $\left(P_{0.99}\right)$ of $\mathrm{YP}, \mathrm{KP}, \mathrm{CP}_{1}$ and $\mathrm{CP}_{2}$ are $15 \%, 20 \%, 10 \%$ and $20 \%$ with the average heterozygosities $\left(H_{o}\right)$ of $0.014 \pm 0.007,0.020 \pm 0.010,0.010 \pm 0.007$ and $0.033 \pm 0.017$, respectively. The mean effective allele number $(\mathrm{Ne})$ of these four populations are 1.015 $\pm 0.008,1.023 \pm 0.011,1.011 \pm 0.007$ and $1.042 \pm 0.022$ while the heterozygous divergent indexes $(D)$ of them value $+0.037,-0.030,-0.098$ and -0.030 , respectively. The genetic similarity in$\operatorname{dex}(I)$ and genetic distance $\left(D_{n e i}\right)$ between two wild geographic populations are 0.99998 and 0.00002 , respectively.
\end{abstract}

Key words : Penaeus chinensis, genetic diversity , isozyme, horizontal starch gel electrophoresis , conservation biology

\section{Introduction}

Penaeus chinensis shrimp has been playing an economically important role in the fishing and farming industries in northern China. The maximum catches in an autumn fishing season used to reach 40000 MT in 1970's ( Deng et al. ,1990). During the major onset of shrimp mariculture from 1989 to 1992 , the shrimp farming scale summed up to $150000 \mathrm{hm}^{2}$ with an annual harvest of some 200,000 MT , which made China a leading producer of cultured shrimp in the world (Cen , 1993). Fatally, due to overfishing and shrimp diseases, since 1993 , the shrimp landings in autumn fishing season was declining to less than 1000 ton ( Deng \& Zhuang ,2001) , while the shrimp cultivation harvest has dramatically dropped to a yearly harvest about $25 \%$ of that before 1992 .

In the last two decades, up to one billion shrimp ( $P$. chinensis) larvae have been annually released into the Yellow Sea and Bohai Sea to replenish the decreasing stock. From the genetic point of view, the genetic structure of natural shrimp population may be affected by those genetically unsafe larvae released or escaped from shrimp farms. The smaller spawning stock and the deteriorated spawning environment can affect the natural population genetic structure as well. To protect this valuable marine resource and supply with genetic background for a select breeding program, it is vitally necessary to investigate and evaluate the genetic diversity in the natural and cultivated shrimp populations.

The isozyme technology has been widely applied to investigate and assess the genetic variation within or among populations ( Yu et al. , 1997). This study primarily reported the genetic variation of $P$. chinensis by means of isozyme analysis.

\section{Materials and Methods}

Two wild geographic populations and two cultivated populations of $P$. chinensis were investigated. The sampling information is listed in Table 1. Fifty live shrimp of each population were collected and kept in dry ice on the way to the lab. The muscle and liver tissues

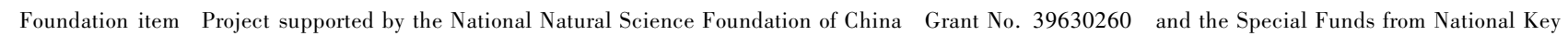
Basic Research Program of China (Grant No. G1999012007). 
were dissected from each shrimp and preserved in deep freezer at $-86^{\circ} \mathrm{C}$ as the sub-sample.

$0.2 \sim 0.3 \mathrm{~g}$ sub-sample of tissue was homogenized in 5 volume $0.1 \mathrm{~mol} / \mathrm{L}$ Tris-HCl $(\mathrm{pH} 7.0)$ with icebath. Homogenates were centrifuged and $15000 \mathrm{rpm}$ for $15 \mathrm{~min}$ at $4{ }^{\circ} \mathrm{C}$ to obtain supernatants. Electrophoresis was performed using a $12 \% \sim 14 \%$ starch gel consisting of potato and soluble starch, which was pre- pared according to Wang ( 1996 ). The particulars of buffers and running conditions were as follows: TC 6.9 , Tris-citrate , $\mathrm{pH} 6.9,8 \mathrm{v} / \mathrm{cm} 12 \mathrm{~h}$; TC8.0 , Triscitrate, $\mathrm{pH} 8.0,12 \mathrm{v} / \mathrm{cm} 10 \mathrm{~h}$ and TMME, Tris-Maleicacid- $\mathrm{MgCl}_{2}$-EDTA , pH 8.2, $15 \mathrm{v} / \mathrm{cm} 15 \mathrm{~h}$ (Wang , 1996 ; Wang et al. , 1996). The gels were then sliced and the related histochemical stain used to each slice (Table 2). Stain recipes were applied

\section{Table 1 Details of shrimp sampled}

\begin{tabular}{|c|c|c|c|c|}
\hline Population & Sampling location & $\begin{array}{l}\text { Sampling } \\
\text { date }\end{array}$ & $\begin{array}{l}\text { Number of } \\
\text { individuals }\end{array}$ & $\begin{array}{l}\text { Body length of } \\
\text { samples }(\mathrm{cm})\end{array}$ \\
\hline $\begin{array}{l}\text { Population in the western coast } \\
\text { of Korean Peninsula ( KP) }\end{array}$ & $\begin{array}{l}\text { The western coast of Korea Peninsula } \\
\qquad\left(35^{\circ} 34^{\prime} \mathrm{N}, 126^{\circ} \mathrm{E}\right)\end{array}$ & May. 1998 & 50 & $12 \sim 15$ \\
\hline $\begin{array}{l}\text { Population in the China coast of } \\
\text { the Yellow Sea ( YP) }\end{array}$ & $\begin{array}{c}\text { The Haizhou Bay of the } \\
\text { Yellow Sea }\end{array}$ & Aug. 1998 & 50 & $11 \sim 12$ \\
\hline Cultivated population I $\left(\mathrm{CP}_{1}\right)$ & A shrimp farm in Jimo, Shandong & Aug. 1998 & 50 & $9 \sim 12$ \\
\hline Cultivated population II $\left(\mathrm{CP}_{2}\right)$ & $\begin{array}{c}\text { Health Shrimp Farming Demonstration } \\
\text { Base in Jimo, Shandong }\end{array}$ & Aug. 1998 & 50 & $9 \sim 11$ \\
\hline
\end{tabular}

Table 2 Enzymes assayed, buffer systems used and number of loci scored

\begin{tabular}{|c|c|c|c|c|}
\hline Enzyme & E. C. No. & Tissue & Buffer system & No. of loci scored \\
\hline Lactate Dehydrogenase LDH & E. C. 1.1.1.27 & Muscle & TC6.9 & 1 \\
\hline Malate Dehydrogenase MDH & E. C. 1.1 .1 .37 & Muscle & TC8. 0 & 2 \\
\hline Malic Dehydrogenase ME & E. C. 1.1 .1 .30 & Muscle & TC6. 9 & 1 \\
\hline Isocitrate Dehydrogenase IDH & E. C. 1.1 .1 .42 & Muscle & TC6. 9 & 1 \\
\hline Acid Phosphatase ACP & E. C. 3.1.3.2 & Liver & TC8. 0 & 4 \\
\hline Alkaline Phosphatase ALP & E. C. 3.1.3.1 & Liver & TC8. 0 & 3 \\
\hline Phosphoglucomutase PGM & E. C. 2.7 .5 .1 & Muscle & TC8. 0 & 3 \\
\hline Glucose Phosphate Isomerase GPI & E. C. 5.3.1.9 & Muscle & TC8. 0 & 1 \\
\hline Adenylate Kinase AK & E. C. 2.7. 4.3 & Muscle & TC8. 0 & 1 \\
\hline Glucose-6-Phosphate Dehydrogenase G6PDH & E. C. 1.1 .1 .44 & Muscle & TMME & 1 \\
\hline Glutamate Dehydrogenase GDH & E. C. 1.4 .1 .4 & Liver & TC8. 0 & 1 \\
\hline Sorbital Dehydrogenase SORD & E. C. 1.1 .1 .14 & Liver & TC8. 0 & 1 \\
\hline Esterase EST & E. C. 3.1.1.1 & Liver & TC8. 0 & 4 \\
\hline
\end{tabular}

subject to the protocols ( Wu \& Lin , 1983 ; Harris \& Hopkinson , 1976 ; Wang , 1996$)$. The nomination of loci and description of alleles were conducted according to Shaklee et al. (1989). Loci are nominated according to the relative abbreviation of enzyme encoded. If an enzyme is encoded by multiple loci, allelic variants are designated according to their relative mobilities. The most common allele is designated 100 and the others are given numbers according to their mobilities correspondingly to that of the common allele. To assess the genetic structures of these four populations , proportion of polymorphic loci $(P)$, effective number of alleles per locus $(\mathrm{Ne})$, allelic frequency, observed heterozygosity ( $\mathrm{Ho}$ ), expected heterozygosity $(\mathrm{He})$ and divergent index $(D)$ at Hardy-Weinberg equilibrium were calculated ( Wang , 1996). The genetic similarity $(I)$ and genetic distance $(d)$ were also applied to estimate the enzyme variation between the YP and the KP ( Wang , 1996).

\section{Results}

The experiment totally investigated 13 enzymes. Twenty loci encoding 12 enzymes were scored and used for genetic analysis except for Esterase due to its complex banding pattern ( Table 3 ). As Table 3 listed, the frequencies of the most common alleles in $\mathrm{YP}, \mathrm{KP}$ and $\mathrm{CP}_{1}$ were above 0.92 , but those in $\mathrm{CP}_{2}$ could range from 0.80 to 1.00 . 
Variant alleles were detected at the $s M d h, P g m$ $a, P g m-c$ and Gpi loci (Figs. 1 3). A variant allele at Pgm-c locus (Pgm-c89) was detected among the samples of $\mathrm{YP}, \mathrm{KP}$ and $\mathrm{CP}_{2}$, but can not be detected in $\mathrm{CP}_{1}$. The values of the observed and expected heterozygosities ( $\mathrm{Ho} \& \mathrm{He}$ ), divergent index $(D)$ and effective number of alleles ( $\mathrm{Ne}$ ) for each polymorphic locus are given in Table 4. Among these 4 polymorphic loci , Pgm-a showed relatively high variability consistently in all four populations and the variability of the others varied with different populations, e. g. the higher variability of $s M d h$ was found in KP and that of $G p i$ in $\mathrm{CP}_{2}$. The minus $D$ values were found at $G p i$ locus of $\mathrm{KY}$ and $\mathrm{CP}_{1}$ as well as $\mathrm{CP}_{2}$.

Across these 20 loci (Table 3 ) , considering a locus polymorphic if the frequencies of the most common alleles were less than $0.99\left(P_{0.99}\right)$, the mean proportions of polymorphic loci were $20 \%$ for both KP and $\mathrm{CP}_{2}, 15 \%$ for $\mathrm{YP}$ and $10 \%$ for $\mathrm{CP}_{1}$. Table 5 summarizes the estimates of genetic variation in these four populations of $P$. chinensis.

Table 3 Allele frequencies in four populations of $P$. chinensis

\begin{tabular}{|c|c|c|c|c|c|}
\hline \multirow{2}{*}{ Locus } & \multirow{2}{*}{ Allele } & \multicolumn{4}{|c|}{ Population } \\
\hline & & YP & KP & $\mathrm{CP}_{1}$ & $\mathrm{CP}_{2}$ \\
\hline$L d h$ & 100 & 1.00 & 1.00 & 1.00 & 1.00 \\
\hline \multirow[t]{2}{*}{$s M d h$} & 100 & 0.99 & 0.95 & 0.99 & 0.92 \\
\hline & 133 & 0.01 & 0.05 & 0.01 & 0.08 \\
\hline$m M d h$ & 100 & 1.00 & 1.00 & 1.00 & 1.00 \\
\hline$M e$ & 100 & 1.00 & 1.00 & 1.00 & 1.00 \\
\hline Idh & 100 & 1.00 & 1.00 & 1.00 & 1.00 \\
\hline Acp-a & 100 & 1.00 & 1.00 & 1.00 & 1.00 \\
\hline$A c p-b$ & 100 & 1.00 & 1.00 & 1.00 & 1.00 \\
\hline Acp-c & 100 & 1.00 & 1.00 & 1.00 & 1.00 \\
\hline Acp-d & 100 & 1.00 & 1.00 & 1.00 & 1.00 \\
\hline Alp-a & 100 & 1.00 & 1.00 & 1.00 & 1.00 \\
\hline$A l p-b$ & 100 & 1.00 & 1.00 & 1.00 & 1.00 \\
\hline Alp-c & 100 & 1.00 & 1.00 & 1.00 & 1.00 \\
\hline \multirow[t]{2}{*}{ Pgm-a } & 100 & 0.94 & 0.92 & 0.94 & 0.8 \\
\hline & 10 & 0.06 & 0.08 & 0.0 & 0.13 \\
\hline$P g m-b$ & 100 & 1.00 & 1.00 & 1.00 & 1.00 \\
\hline \multirow[t]{2}{*}{$P g m-c$} & 100 & 0.97 & 0.9 & 1.00 & 0.98 \\
\hline & 89 & 0.03 & 0.03 & 0.00 & 0.02 \\
\hline \multirow[t]{2}{*}{$G p i$} & 100 & 0.9 & 0.94 & 0.95 & 0.80 \\
\hline & 8 & 0.04 & 0.0 & 0.05 & 0.20 \\
\hline$A k$ & 100 & 1.00 & 1.00 & 1.00 & 1.00 \\
\hline$G p d h$ & 100 & 1.00 & 1.00 & 1.00 & 1.00 \\
\hline$G d h$ & 100 & 1.00 & 1.00 & 1.00 & 1.00 \\
\hline Sord & 100 & 1.00 & 1.00 & 1.00 & 1.00 \\
\hline
\end{tabular}

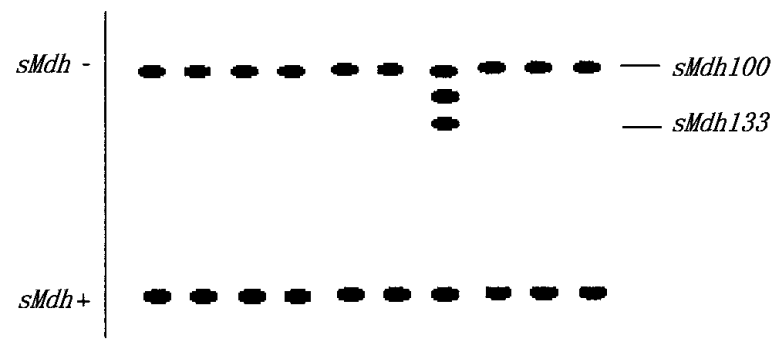

Fig. 1 Zymogram and its interpretation of $\mathrm{MDH}$ in $\mathrm{YP}$ of $P$. chinensis

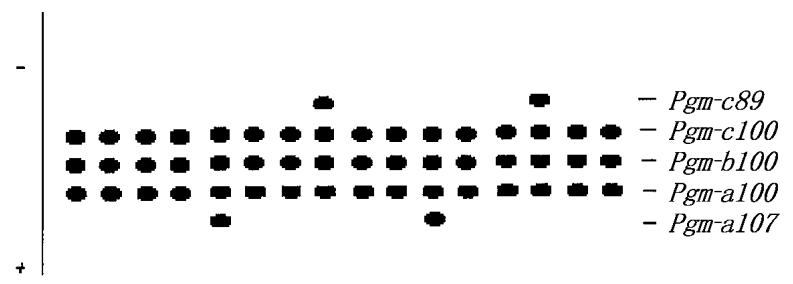

Fig. 2 6ymogram and its interpretation of PG7 in YP of $P$. chinensis

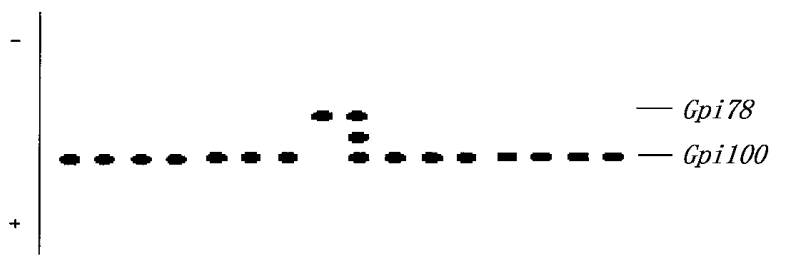

Fig. 3 6ymogram and its interpretation of DPI in $\mathrm{CP}_{1}$ of $P$. chinensis

\section{Discussion}

This study primarily investigated the genetic diversity at 20 enzyme loci in four populations of Penaeus chinensis with the average proportions of polymorphic loci ranging from $10 \%$ to $20 \%$, which are quite similar to previous electrophoresis studies on Penaeid shrimp with a polymorphism range from $11 \%$ to $33 \%$ (Marris et al. , 1990 ; Medgecock et al. , 1982 ; Lester , 1983 ; 7 ulley \& Later , 1980 ; Sbordoni et al. , 198 ; I unden \& Z avis , 1991 ; 6huang et al. ,2000). The relevant results through the starch gel electrophoresis examination of isozyme variability support a conclusion that Penaeid shrimps exhibit relatively low polymorphism level due to fewer polymorphic loci that could be detected. H this study , the average heterozygosities observed in the four populations of $P$. chinensis varied from 0.010 to 0.033 , which were within the limits of the heterozygosities ( $0.00 \sim 0.09)$ observed in other Penaeid shrimps, but much less than 0.03 in crustaceans and 
Table 4 The observed and expected heterozygosities ( $\mathrm{Ho} \& \mathrm{He}$ ), divergent index ( $\mathrm{D}$ ) and effective number of alleles ( $\mathrm{Ne}$ ) at each polymorphic locus

\begin{tabular}{|c|c|c|c|c|c|}
\hline Loci & Estimates & YP & KP & $\mathrm{CP}_{1}$ & $\mathrm{CP}_{2}$ \\
\hline \multirow{4}{*}{$s M d h$} & Ho & 0.02 & 0.10 & 0.02 & 0.16 \\
\hline & $H e$ & 0.0198 & 0.095 & 0.0198 & 0.1472 \\
\hline & $D$ & +0.0101 & +0.0526 & +0.0101 & +0.0870 \\
\hline & $N e$ & 1. 0204 & 1. 1111 & 1. 0204 & 1. 1905 \\
\hline \multirow{4}{*}{ Pgm-a } & Ho & 0.12 & 0.16 & 0.12 & 0.26 \\
\hline & $H e$ & 0.1128 & 0.1472 & 0.1128 & 0.2262 \\
\hline & $D$ & +0.0638 & +0.0087 & +0.0638 & +0.1494 \\
\hline & $N e$ & 1. 1364 & 1. 1905 & 1. 1364 & 1. 3514 \\
\hline \multirow{4}{*}{$P g m-c$} & Ho & 0.06 & 0.06 & 0 & 0.04 \\
\hline & $H e$ & 0.0582 & 0.0582 & 0 & 0.0392 \\
\hline & $D$ & +0.0309 & +0.0309 & l & +0.0204 \\
\hline & $\mathrm{Ne}$ & 1.0638 & 1.0638 & I & 1.0417 \\
\hline \multirow{4}{*}{$G p i$} & Ho & 0.08 & 0.08 & 0.06 & 0.20 \\
\hline & $H e$ & 0.0768 & 0.1128 & 0.095 & 0.32 \\
\hline & $D$ & +0.0417 & -0.2908 & -0.3684 & -0.375 \\
\hline & $N e$ & 1.0870 & 1.0870 & 1.0638 & 1. 25 \\
\hline
\end{tabular}

Table 5 Estimates of genetic variation in four populations of Penaeu chinensh

\begin{tabular}{ccccc}
\hline & $\mathrm{YP}$ & $\mathrm{KP}$ & $\mathrm{CP}_{1}$ & $\mathrm{CP}_{2}$ \\
\hline$P_{0.99}$ & $15 \%$ & $20 \%$ & $10 \%$ & $20 \%$ \\
$H o$ & $0.014 \pm 0.007$ & $0.020 \pm 0.010$ & $0.010 \pm 0.007$ & $0.033 \pm 0.017$ \\
$H e$ & $0.013 \pm 0.007$ & $0.021 \pm 0.010$ & $0.011 \pm 0.007$ & $0.037 \pm 0.020$ \\
$D$ & +0.037 & -0.030 & -0.098 & -0.030 \\
$N e$ & $1.015 \pm 0.008$ & $1.023 \pm 0.011$ & $1.011 \pm 0.007$ & $1.042 \pm 0.022$ \\
\hline
\end{tabular}

0.051 in Penaeoidea and Caridea (Hedgecock et al. , $1982)$.

As listed in Table 5 , the average values of $H o$ and $N e$ present a declining gradient of $\mathrm{CP}_{2} \rightarrow \mathrm{KP} \rightarrow \mathrm{YP} \rightarrow$ $\mathrm{CP}_{1}$. But there exists a significant difference of $D$ values among these four populations (Table 4,5). Due to no rare homozygous genotype was detected in $\mathrm{YP}$, the rare allele (Gpi78) was inherited by heterozoygotes. Being of lower genetic variation in Penaeus chinensis shrimp, the function of those heterozygotes performing inheritance of rare alleles might be over-estimated. As a result, the $D$ value denotes positive. Besides , minus $D$ values occurred in $\mathrm{CP}_{2}$ and $\mathrm{CP}_{1}$ as well as KP , suggesting a critical deficit of heterozygotes on the assumption of Hardy-Weinberg equilibrium in these three populations. The most likely explanation to this result obtained in this study may be : a) the occurrence of rare homozygous genotypes at $G p i$ locus resulted in the heterozygote deficiency in $\mathrm{CP}_{2}$ and $\mathrm{CP}_{1}$ as well as $\mathrm{KP}$ and $\mathrm{b}$ ) the performance of rare homozygous genotype inheriting rare allele, to some extent, dominates that of heterozygous genotype. Having analyzed a species of deep-sea shrimp (Rimicaris exoculata) , Crea- sey et al. (1996) revealed that heterozygote deficiency could be caused by the occurrence of rare homozygous genotypes.

Unfortunately, very little research work was conducted to reveal the genetic background of $P$. chinensis before its resource collapsed and the hatchery release conducted. According to Deng et al. (1990), there exists two geographic populations of $P$. chinensis in the Yellow Sea and Bohai Sea, one is distributed in the Yellow Sea and the Bohai Sea (YP), and the other in the western coast of the Korean Peninsula (KP). These two populations share the same over-wintering ground in the central to southern part of the Yellow Sea but their spawning and feeding grounds are completely different. Based on the biological characters, these two populations were reproductively isolated from each other. The genetic similarity index $(I)$ and genetic distance $\left(D_{n e i}\right)$ between YP and KP are 0.99998 and 0.00002 , respectively, which means less differentiation between two populations. But the genetic diversity in $\mathrm{YP}$ is, to some extent, poorer than that in KP. This may be correlated with human activities like hatchery release on large scale and shrimp farming industry. 
At present, there has been no artificially selected breed shrimp in mariculture. Most of the domesticated brood stocks belong to the wild strains. Bottleneck effect from the genetically unwarranted brood stocks, including quality and quantity, may be the main causes of the loss of progeny genetic diversity. Furthermore, most of the shrimp farms adopt the closed or hemiclosed farming models currently, inbreeding may be another reason why the shrimp genetic variation loses (Sbordoni et al . , 1986, Qiu , 1998 ). As indicated by the mean heterozygosity observed value of $0.010 \pm$ 0.007 and the mean proportion of ploymorphic loci of $10 \%, \mathrm{CP}_{1}$ possesses lower genetic variation level than that of YP.

Since the natural $P$. chinensis resource has been destroyed and its genetic variation has been threatened, it is of great significance to restore the genetic diversity, at the beginning of which, to select beneficially genetic markers for high yield and disease-resistant strains is the priority to shrimp farm industry. $\mathrm{CP}_{2}$ is regarded as a high-health cultivated stock by selective breeding. The values of $\mathrm{Ho}$ and $P_{0.99}$ in $\mathrm{CP}_{2}$ are 0.033 and $20 \%$, respectively. The higher genetic diversity level in $\mathrm{CP}_{2}$ encourages the further work on selective breeding. Moreover, Pgm-a and Gpi loci possess higher genetic variation in $P$. chinensis, which is accordant with the previous reports on other shrimp species (Villaescusa et al. , 1984 ; Nevo et al. , 1981 ). From this point of view, PGM and GPI can be used as the special protein markers of $P$. chinensis for genetic diversity assessment and selective breeding program.

\section{References}

Cen F, 1993. Retrospect and prospect of aquaculture industry in China. Modern Fisheries Information, 8(1): 2 (in Chinese)

Creasey S, Rojers A D and Tyler P A, 1996. Genetic comparison of two populations of the deep-sea vent shrimp Rimicaris exoculata (Dacapoda: Breisliidad) from the Mid-Atlantic (Atlantic) Ridege. Marine Biology, 125(3): $473 \sim 482$

Deng J Y, Ye C C and Liu Y C, 1990. Penaeid Shrimp - Its Biology and Management in the Yellow-Bohai Seas. Beijing: Ocean Press, $38 \sim 39$

Deng J Y and Zhuang Z M, 2001. The cause of recruitment variation of Penaeus chinensis in the Bohai Sea. Journal of Fishery Sciences of China, 7(4): $125 \sim 128$

Harris D K and Hopkinson N A, 1976. Handbook of Enzyme Electrophoresis in Human Genetics. Oxford: North-Holland publishing Com

Harris S E G, Dillion R T J and Sandifer P A, 1990. Electrophoresis of isozymes in cultured Penaeus vannamei. Aquaculture, $85(1 \sim 4): 330$

Hedgecock D, Tracey M and Nelson K, 1982. Genetics. In: Bliss D E (eds.), The Biology of Crustacean. Vol. 2. mryology, morphology, and genetics. New York: Academy Press, $284 \sim 403$

Lester L J, 1983. Developing a selective breeding program for Penaeid shrimp mariculture. Aquaculture, 33(1 4): $41 \sim$ 45

Mulley J C and Later B D H, 1980. Genetic variation and evolutionary relationship within a group of thirteen species of Penaeid prawns. volution, 34:904 916

Nevo E, Perl T, Beiles A and Wool D, 1981. Mercury selection of allozyme genotypes in shrimps. Ecperientia. Basel, 37 (11) : $1152 \sim 1154$

Qian Y Q and Ma K P, 1994. Principles and Methodologies of Biodiversity Studies. Beijing: Chinese Science and Technology Press, 132

Qiu G F, 1998. A review of genetics and breeding in shrimps (prawns) and crabs. Journal of Fisheries of China, 22(3): $265 \sim 274$

Sbordoni V, Matthaeis E D and Cobdli S, 1986. Bottleneck effects and the depression of genetic variability in hatchery stocks of Penaeus japonicus (Crustacea: Decapoda). Aquaculture, 57: $239 \sim 251$

Sunden S L F and Davis S K, 1991. Evaluation of genetic variation in a domestic population of Penaeus vannamei (Boone): a comparison with three natural populations. Aquaculture, 97 $(1 \sim 4): 131 \sim 142$

Shaklee J B, Allendorf F W and Morizot D C, 1989. Genetic nomenclature of protein-coding loci in fish proposed guidelines. Transaction of America Fishery Society, 118: 218 227

Tam Y K and Chu K, 1993. Electrophoretic study on the phylogenetic relationships of some species of Penaeus and Metaplenaeus (Decapoda: Penaeidad) from the South China Sea. Journal of Crustacean Biology, 13(4) : $697 \sim 705$

Villaescusa A, Camacho A and Rivalta V, 1984. Phosphoglucose isomomerase and phosphoglucomutase polymorphism in the pink shrimp, Penaeus notialis, Ciencias oilicas. Havana, 12: $23 \sim 30$

Wang K L, You F, Xu C and Wu S Q, 1996. The specific expression of isozymes in different tissues and preliminary biochemical genetic analysis based on the electrophoresis of five marine fishes. Oceanologia et limnologia sinica, 27 (6) : $626 \sim 631$

Wang K L, 1998. Isozyme Principle, Method and Application in Fishes. In: Zeng C K and Xiang J H (eds.), Marine Biotechnology (in Chinese). Jinan: Science and Technology Press of Shandong. $283 \sim 316$

Wang Z R, 1996. Plant Allozyme Analysis. Beijing: Science Press, $77 \sim 119 ; 145 \sim 154$

Wu H L and Lin J H, 1983. Experimental Methods and Tech- 


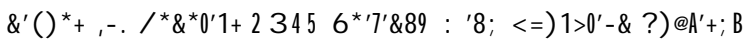
' $88:-)+5$ ! \#C D! EC

F) GHI J - \$8 K FI F $>\$ 8 \mathrm{LI} \quad M>\$ 8 \mathrm{~L} \mathrm{~N}>\delta=0$ ) $6 \mathrm{PI} Q / 8 E 5$ RAASTU* V $>:^{\prime}>0-\& W 0$ ' $\left.\& X-X\right) \rightarrow 0-\&+-, Y^{*} 8^{\prime} A>1>8 .>\&+\rightarrow 5$ Journal of Fishery Sciences of China, 4Z\9व D! Q

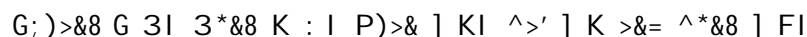

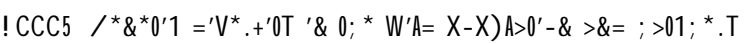

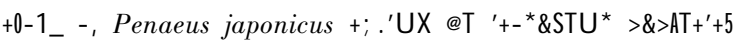
Zoological Research, 21Z”\9'!‘ D’! \#

\section{中国对虾 (Penaeus chinensis) 4 个种群的同工酶遗传变异}

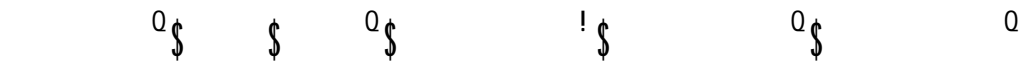

$\mathrm{Q}$ (中国水产科学研究院黄海水产研究所,\$青岛\$! \#CEQ)

! ( 青岛海洋大学海洋生命学院, \$青岛\$! \#CC)

摘要: 采用水平淀粉凝胶电泳技术分析了中国对虾 (Penaeus chinensis) 黄渤海沿岸种群 ( $\mathrm{F}$ ?)、朝鲜半岛西海岸种群 (J ?) 和! 个养殖种群 ( N? 和 N?! ) 的同工酶遗传变异水平。每个种群随机选取 [ C 尾中国对虾进行同工酶检测。 在所分析的 $\mathrm{Q}$ 种同工酶编码的! C个基因位点中, 有 " 个是多态位点。" 个种群的多态位点比例 ( $P_{\mathrm{C} \%}$ \% 分别为 $Q a 、 ! C a 、 Q C a$ 和 ! Ca 。种群平均杂合度 (观测值) ( Ho ) 分别为 C5CQ' b C5CCE、C5C! C b C5COC、C5COC b C5CCE 和 $\mathrm{C5C}$ “ b C5CQE。” 个种群的位点有效等位基因数 ( $\mathrm{Ne}$ ) 分别为 Q5CQ b C5CCC、Q5C! ‘ b C5COQ Q5COQ b C5CCE 和 Q5C"! $\mathrm{bC5C}$ ! 。杂合子平衡偏离指数 $(D)$ 分别为 d C5C E、e C5C C、e C5C\% 和 e C5C C。！个地理种群 ( F ? 和 J ? ) 的遗 传相似性系数 $(I)$ 和遗传距离 $\left(D_{n e i}\right)$ 分别为 C5\%88/6 和 C5CCCCC 。

关键词：中国对虾 (Penaeus chinensis)，遗传多样性，同工酶，水平淀粉凝胶电泳，保护生物学

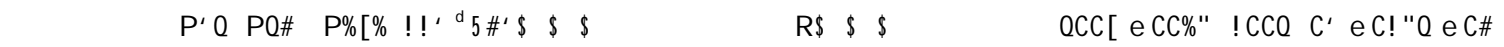

